\title{
Opportunities regarding the use of technologies of energy recovery from sewage sludge
}

\author{
Anca Maria Zaharioiu ${ }^{1,2} \cdot$ Felicia Bucura$^{1} \cdot$ Roxana Elena lonete ${ }^{1} \cdot$ Florian Marin $^{1} \cdot$ Marius Constantinescu $^{1}$. \\ Simona Oancea ${ }^{2}$
}

Received: 12 March 2021 / Accepted: 5 August 2021

Published online: 16 August 2021

(c) The Author(s) 2021 OPEN

\begin{abstract}
Based on the global need to efficiently eliminate highly produced amounts of sewage sludge, alternative technologies are required to be practically developed. Reduction of sewage sludge waste quantities with energy recovery is the most important and modern practice, with least possible impact on the environment. Appropriate technologies for treating and disposal sewage sludge are currently considered: incineration, gasification and pyrolysis. The main products generated during the pyrolysis process are bio-gas, bio-oil and bio-residue, providing sustainable fuels/ biofuels and adsorbents. Compared to other disposal methods of sewage sludge, pyrolysis has advantages in terms of the environment: waste in small quantities, low emissions, low level of heavy metals. From a technological point of view, pyrolysis is the most efficient in relation to its final products, pyrolysis oil, pyrolysis gas and solid residue that can be transformed into $\mathrm{CO}_{2}$ adsorbent with the help of chemical and thermal activation processes. The incineration process of sewage sludge has a number of disadvantages both environmentally and technologically: organic pollutants, heavy metals, toxic pollutants and ash resulting from combustion that needs a disposal process. A comparison of different types of sewage sludge elimination for the energy recovery is described in the present paper.
\end{abstract}

\section{Article Highlights}

- Sewage sludge is a waste in increasing quantities, which requires disposal and energy recovery, in a clean way for the environment.

- The pyrolysis process of sewage sludge is the cleanest method of its recovery. Pyrolysis products, bio-oil, syngas and biochar, can be used as alternative fuels to fossil fuels.

- The pyrolysis process of the sewage sludge is the most advantageous from the point of view of the obtained products and of the environment, in comparison with the incineration and gasification processes.

Keywords Sewage sludge $\cdot$ Valorization $\cdot$ Pyrolysis · Gasification

$\triangle$ Anca Maria Zaharioiu, ancadumi4@yahoo.com | ${ }^{1}$ National Research and Development Institute for Cryogenic and Isotopic Technologies - ICSI Rm. Valcea, 4 Uzinei Str., 240050 Ramnicu Valcea, Romania. ${ }^{2}$ Faculty of Agricultural Sciences, Food Industry and Environmental Protection, Lucian Blaga" University of Sibiu, 7-9 I. Ratiu Str., 550012 Sibiu, Romania. 


\section{Introduction}

The global production of sewage sludge has increased in recent years and is constantly growing, the sewage sludge (SS) being a by-product resulting from the wastewater treatment process [1]. The main challenge is the removal of sewage sludge, which is a real toxic cocktail due to pollution and heavy metals. At the same time, the world's population is facing another challenge, namely the energy deficit. In order to overcome this energy deficit, alternative energy from renewable sources must be developed, with environmental protection measures. Because of these problems, the sewage sludge is suitable for the development of renewable energy through various processes [2].

Sewage sludge may contain pathogenic microorganisms, parasites or several toxic compounds, such as heavy metals, polycyclic aromatic hydrocarbons, dioxins and furans. High amounts of SS, 60 million tons, of $80 \%$ moisture have been reported in China, with potential of increasing by $10 \%$ each year [2]. While in EU, the increasing SS amounts can reach about 13 million tons in the 2020 year. In Table 1 is presented the quantity of sewage sludge in different countries for several years.

The traditional methods currently used to eliminate SS are composting for use in agriculture, gasification, pyrolysis and incineration. Lately, composting of SS is prohibited due to the strong smell, leachate, spread of pathogenic microorganisms and environmental contamination with toxic compounds [4]. Incineration of SS has a number of negative side effects, among them emissions of greenhouse gas, dioxins and furans being a great concern. Moreover, the resulted ash must also be removed by an additional treatment [5]. This method requires large amounts of energy which limits the development and implementation of such technology. The European Commission task is the reduction of waste by $50 \%$ until 2050 [6]. This category also includes SS from the wastewater treatment plants (category 19 of the waste code) in accordance with the Decision no. 856/2002 [7]. EU studies showed that $53 \%$ of produced SS is used for the final disposal, used in agriculture/composting, while only $20 \%$ is used for incineration.

As shown in Figs. $1 \mathrm{a}, \mathrm{b}$ and 2, SS can be used in the manufacture of construction materials, land application and incineration. Even if these possible usages have been identified, a significant amount of SS is eliminated by improper discharge. The methods of treatment and disposal of SS varies from one country to another depending on its socio-economic development and the legal requirements [8].

Because of the global need to properly eliminate SS, alternative technologies have been emerged in order to
Table 1 Annual production of sewage sludge (unit of measure in thousand of tonnes) in Europe, by country, during 2016-2018 [3]

\begin{tabular}{|c|c|c|c|}
\hline Country & 2016 & 2017 & 2018 \\
\hline Belgium & - & - & - \\
\hline Bulgaria & 65.8 & 68.6 & - \\
\hline Czech Republic & 206.71 & 223.27 & 228,22 \\
\hline Denmark & - & - & - \\
\hline Germany & - & - & - \\
\hline Estonia & 18.34 & - & - \\
\hline Ireland & 56.018 & 58.773 & - \\
\hline Greece & 119.768 & - & - \\
\hline Spain & 1174.4 & - & - \\
\hline France & 1006 & 1174 & - \\
\hline Croatia & 19.72 & 17.6 & 19.23 \\
\hline Italy & - & - & - \\
\hline Cyprus & 7.408 & 7.166 & 8.406 \\
\hline Latvia & 25.923 & 24.94 & 24.591 \\
\hline Lithuania & 44.422 & 42.488 & 44.192 \\
\hline Luxembourg & 8.918 & 8.618 & 8.28 \\
\hline Hungary & 215.078 & 264.713 & 217.842 \\
\hline Malta & 10.77 & 10.3 & 8.28 \\
\hline Netherlands & 347.6 & - & 341.03 \\
\hline Austria & 237.938 & - & 234.481 \\
\hline Poland & 568.329 & 584.454 & 583.07 \\
\hline Portugal & 119.17 & - & - \\
\hline Romania & 240.41 & 283.34 & 247.76 \\
\hline Slovenia & 32.8 & 36.7 & 38.1 \\
\hline Slovakia & 53.05 & 54.52 & 55.93 \\
\hline Finland & - & - & - \\
\hline Sweden & 204.3 & 205.6 & 210.9 \\
\hline United Kingdom & - & - & - \\
\hline Iceland & - & - & - \\
\hline Liechtenstein & - & - & - \\
\hline Norway & - & - & 147.6 \\
\hline Switzerland & - & 177 & - \\
\hline Montenegro & - & - & - \\
\hline North Macedonia & - & - & - \\
\hline Albania & 94.5 & 98.12 & 94.5 \\
\hline Serbia & 11.2 & 13.3 & 9.6 \\
\hline Bosnia and Herzegovina & 9.5 & 9.5 & 9.5 \\
\hline Turkey & 299.296 & - & 318.503 \\
\hline
\end{tabular}

treat, reduce and eliminate such wastes. Pyrolysis represents an appropriate technology, from which bioenergy can be obtained, while harmful organic substances and pathogens may be eliminated [11]. The residue left after the pyrolysis process can be used for the development of efficient adsorbents $[12,13]$. These adsorbents can be used to reduce the level of heavy metals or organic pollutants $[14,15]$. Thus, pyrolysis can be considered a clean and efficient method of SS disposal [16]. From the 
Fig. 1 Data on different methods of elimination of sewage sludge produced in USA (a) and China (b) [9]

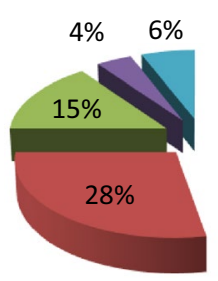

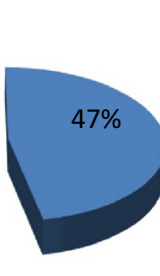

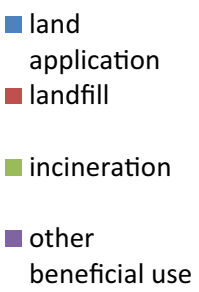

a

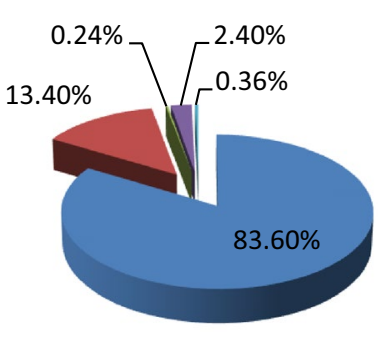

b

\author{
- improper \\ dumpling \\ - landfill \\ building \\ materials \\ a land \\ application \\ incineration
}

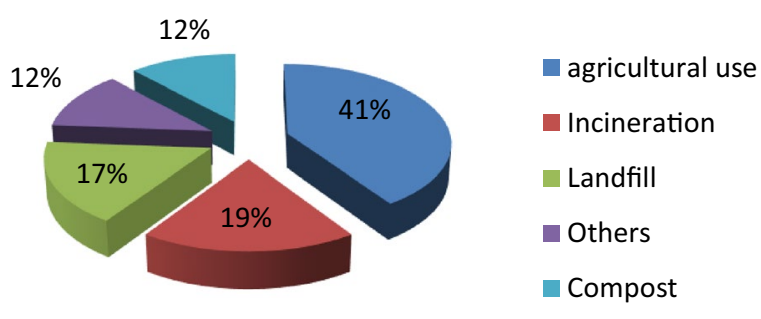

Fig. 2 Sewage sludge usage in Europe according to [10]

pyrolysis process results three types of products: liquid, solid and gaseous. Liquid and gaseous products (bio-oil, bio-gas) can be used as raw or refined materials to obtain chemical fuels, while solid products (bio-residue) can be used as functional materials [17-20]. NOx compounds resulting from the combustion of gases to release energy are considered air pollutants. To reduce air pollution, a nitrogen reduction method for SS pyrolysis must be identified. A number of studies have been conducted to reduce the emission of nitrogen-containing gases during the pyrolysis, as follows: fixation of nitrogen in the solid fraction by pretreatment or roasting [21-26]; mixing the raw material with mineral calcium, $\mathrm{CaO}, \mathrm{Ca}$ and $\mathrm{Na}$ to perform a catalytic pyrolysis [27-30]; changing the conditions under which the pyrolysis process takes place by changing the temperature or atmosphere; transformation of nitrogen-containing gas into $\mathrm{N}_{2}$ [31].

In order to produce large quantities of sustainable energy from SS, there are some technological limits. SS has different physico-chemical properties than conventional solid fuels (biomass or coal) which make processing more difficult and complex [32]. The SS contains nitrogen and phosphorus compounds, non-toxic organic compounds, toxic heavy metals ( $\mathrm{Pb}, \mathrm{Ni}, \mathrm{Cd}, \mathrm{Hg}, \mathrm{As}$ ), organic pollutants (dioxins, pesticides, polycyclic aromatic hydrocarbons), pathogenic bacteria, inorganic compounds (silicates, calcium and magnesium compounds) and a lot of water [33], composition which may largely vary [34]. To reduce the volume of SS that must be treated or removed, the operation of removing excess water is needed. There are two stages of water removal, performed during dehydration and thickening phases $[35,36]$. The moisture content must be considerably reduced so that it can be disposed or used for energy recovery [37]. The SS properties are influenced by the applied technology, season or type of wastewater that enters the treatment plant $[38,39]$. Due to its properties, $\mathrm{SS}$ is considered a fuel based on its high calorific value (10-14 MJ) and high volatiles $[40,41]$.

The purpose of this paper is to describe several sustainable technologies currently applied for SS valorization, including those for energy recovery, and to present an overview of the advantages and disadvantages of applying processes such as gasification, pyrolysis and incineration.

\section{Agriculture valorization}

The sewage sludge used in agriculture has two types of benefits: the recirculation and recycling of important nutrients such as nitrogen and phosphorus and the ecological and adequate disposal of waste from wastewater treatment. The use of sewage sludge as soil fertilizer is beneficial in increasing productivity, but special care must be taken in terms of soil contamination that leads to blockage of ecosystem functions and hence the deterioration of flora, fauna and human health [42-48]

When sewage sludge is used in agriculture, a major problem arises, namely the toxicity of heavy metals that affect the health of humans, animals and plants, which is why the EU has implemented European Council Directive $86 / 278$ /EEC on environmental and soil protection. Before being used in agriculture, sewage sludge goes through a series of biological, chemical, thermal treatment processes, then it is stored for a long time to significantly reduce the sewage sludge fermentation and for safety and health population, plants and animals. After going through a series of processes and stages such as biological stabilization, digestion, composting, the sewage sludge has component nutrients benefical for soil improvement and energy production [49]. The use of SS in agriculture has 
been done for several beneficial effects: improving the physical, chemical and biological soil properties, and supplementation of soils with essential plant nutrients [50, 51]. Unfortunately, SS is a biological residue with a complex chemical structure [52], which may provide potential toxic components to soil through chemical and biological contamination [53]. Plastics and heavy metals are the main contaminants of the soil after fertilization with SS [54], causing the accumulation and transfer of toxic compounds into the environment [55] which negatively influences microorganisms and plant growth $[56,57]$. The risk of contaminating the environment through fertilization soil with sewage sludge is due to the presence of heavy metals, drugs and organic compounds in the sewage sludge. Medicines can reach the environment through several routes, but mainly through sewage, the water from the sewer reaches the treatment plant, and after water treatment they reach the sewage sludge [58-62].

Soil quality and fertility is maintained through microbial activity. From this point of view, sewage sludge has the role and ability to intensify these processes due to the high content of organic matter. The application of a sewage sludge with a low content of heavy metals on the soil has a positive effect on organic carbon, microbial activities and on microbial biomass. On the other hand, if the sewage sludge has large amounts of heavy metals, a negative effect occurs: the decrease of the carbon concentration and activities in the soil [63-66].

Due to the risk of contamination, the $\mathrm{EU}$ has issued the Directive 86/278/EEC, which establishes regulations to combat and prevent possible damage to the environment and to human health, and heavy metals admissable levels, as well [67]. The most frequent contaminants are pharmaceutical compounds, especially antibiotics, which are in fairly large amounts in wastewater because they are poorly metabolized by the human body $[68,69]$. During the wastewater treatment process, antibiotics are not eliminated, reaching the soils for which SS was used as fertilizer. These antibiotics influence different types of the enzymatic transformations in soil [70].

\section{Energy valorization}

Reduction of SS waste quantities aiming the energy recovery is one of the most important and modern practice, with the least possible impact on the environment. Valorization of SS through different methods of energy recovery and the obtained products (bio-gas, bio-residues, bio-oil, heat, ash, tar and other chemical compounds) [71-73] is presented in Fig. 3.

The different methods of SS elimination for energy recovery, comparatively illustrated in Table 2 will be further described.

\subsection{Incineration}

SS incineration aims at the complete oxidation of organic compounds at high temperatures. This process has been used very often in the process of energy recovery, but also in order to reduce the amount of waste:for example, Japan incinerates $70 \%$ of the SS [75].

The incineration process is an important process in the management of wastewater such as sewage sludge. This process leads to the decomposition of toxic organic substances and to the reduction of waste quantities by $70 \%$ $-90 \%[76,77]$. Following the incineration process of the sewage sludge, renewable energy obtained can be used in the form of electricity or heat. After incineration of the sewage sludge, an ash residue results. The resulting ash is considered dangerous due to high concentrations of heavy metals with a negative impact on the environment, and for this reason is used in various fields of industry: in the manufacture of cement and concrete [87] and as road construction materials, for glass and ceramics [78].
Fig. 3 Different methods of enegy recovery from sewage sludge and their products [74]

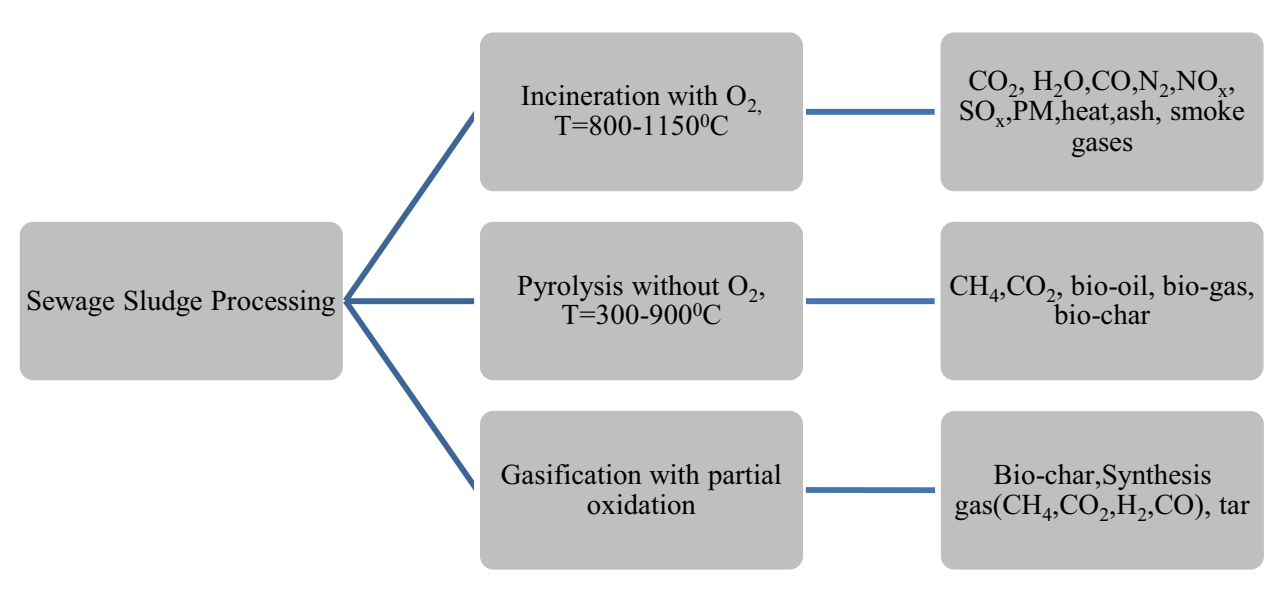


Table 2 Comparison of main characteristics of technologies applied for sewage sludge elimination [74]

\begin{tabular}{|c|c|c|c|c|}
\hline Parameters & Incineration & Pyrolysis & Gasification & Hydrothermal liquefaction \\
\hline Process temperature $\left({ }^{\circ} \mathrm{C}\right)$ & $>850$ & $300-900$ & $750-900$ & $250-370$ \\
\hline Gas production & No & Bio-gas & Synthesis gas & No \\
\hline Oil production & No & Bio-oil & Liquid fuel potential & Liquid bio-crude \\
\hline Char production & No & Bio-char & Tar & \\
\hline Emissions & $\begin{array}{l}\mathrm{CO}_{2}, \mathrm{H}_{2} \mathrm{O}, \mathrm{CO}, \mathrm{N}_{2} ; \mathrm{NO}_{x^{\prime}} \mathrm{SO}_{x^{\prime}} \\
\text { PM, Smoke gases }\end{array}$ & $\begin{array}{l}\text { Low emissions of } \mathrm{CO}_{2} \text { and } \\
\text { heavy metals }\end{array}$ & $\mathrm{CO}, \mathrm{CO}_{2}, \mathrm{H}_{2}, \mathrm{~N}_{2}$ & $\begin{array}{l}\text { Hydrocarbons } \\
\text { Amines and amides }\end{array}$ \\
\hline Costs & High & High & High & \\
\hline Advantages & Heat Electricity & $\begin{array}{l}\text { Low waste Useful } \\
\text { Products(oil, gas, char) }\end{array}$ & Liquid fuel potential & Liquid fuel potential \\
\hline Disadvantages & $\begin{array}{l}\text { Ash waste High moisture } \\
\text { of SS }\end{array}$ & High Moisture of SS & $\begin{array}{l}\text { Toxic effects from the } \\
\text { mixture of heavy metals } \\
\text { and organic pollutants } \\
\text { High Moisture of SS }\end{array}$ & Toxic effects \\
\hline
\end{tabular}

As described in Fig. 4, mechanically dried SS enters the combustor, where SS turns into an inert ash at temperatures $>850{ }^{\circ} \mathrm{C}$ [79]. The incineration process consists in a rapid combustion, chemical reaction with $\mathrm{O}_{2}$ to produce light, and heat release. Oxidation occurs at any temperature, while combustion occurs only at the ignition temperature. The incineration system consists of the following components: sludge supply, mechanical dehydration, dryer, combustor, ash handling system and control devices for air pollution.
Energy recovery by incineration of SS has a number of technological, environmental and societal benefits, but also economic. The advantages of this process are: wellestablished technology, heat generation and electricity; negligible organic pollutants; the possibility of using it together with another solid fuel to reduce greenhouse gases; easy integration of pollutant capture technology; use of existing infrastructure; use together with another solid fuel to reduce costs; energy saving for sewage treatment plants. The disadvantages of this process may include: dehydration of SS as it contains increased

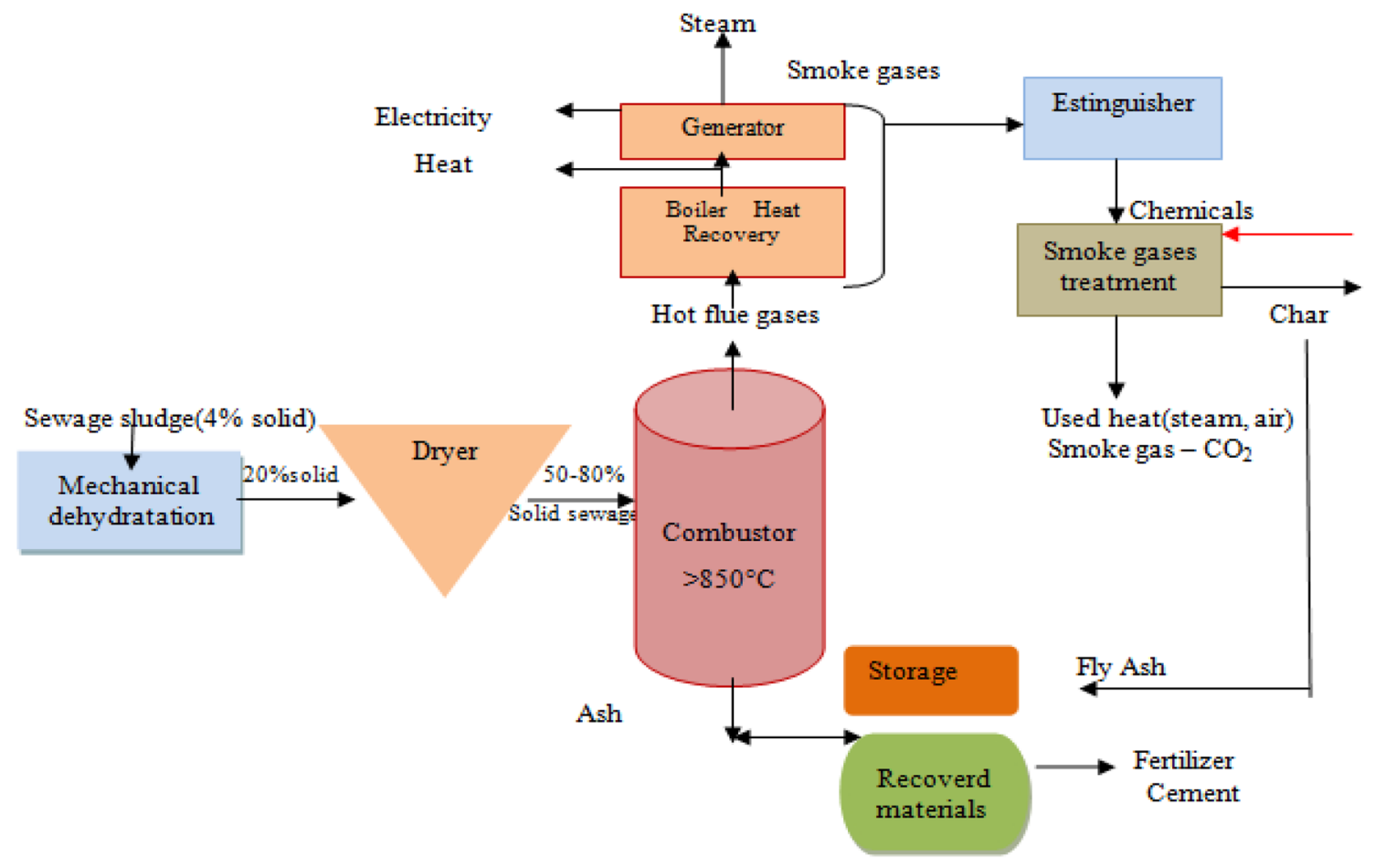

Fig. 4 Incineration of sewage sludge [80] 
moisture; requirement for disposal or reuse of ash waste, $\mathrm{CO}_{2}$, NOx, SOx emissions; public acceptance; high costs for technological cleaning and ash removal; strict control of process pollutants [81].

\subsection{Pyrolysis}

Pyrolysis is a transformation process of sewage sludge in the absence of oxygen and nitrogen atmosphere, which results in 3 types of pyrolysis products: gaseous productpyrolysis gas, liquid product-pyrolysis oil and solid product-pyrolysis residue [82-84]. First time in the pyrolysis process the vapors resulting from the volatile components of the sewage sludge are formed, then the non-volatile substance is decomposed and the following are obtained: residue, tar and gases $[85,86]$. Pyrolysis can be of several types, depending on temperature ranges and residence time: slow pyrolysis, fast pyrolysis. If the temperature is lower and the residence time is longer, then large amounts of pyrolysis residues are produced, if the temperature is medium and the residence time is short, large amounts of bio-oil are produced $[87,88]$.

Pyrolysis oil can also be called bio-oil, is dark brown and can be used as an alternative fuel to fossil fuels after a series of refining and water removal processes. Pyrolysis gas is the non-condensable gas obtained from the pyrolysis process of sewage sludge, such as $\mathrm{H}_{2}, \mathrm{CO}, \mathrm{CO}_{2}, \mathrm{CH}_{4}, \mathrm{C}_{2}$ $\mathrm{H}_{2}, \mathrm{C}_{2} \mathrm{H}_{6}$. These gases can be used in different technologies if were separated and purified $[89,90]$.
Figure 5 shows the pyrolysis process of sewage sludge and products obtained from the process: bio-oil, syngas and bio-char.

The advantages of the pyrolysis process are: minimal amounts of generated waste; production of useful oil, gas and solid residue; use of both raw and digested SS; low emissions and decreased level of heavy metals than from other processes; feasible technology for large treatment plants; low carbon potential for the energy industry. Of course, there are some disadvantages, such as: requirements for dehydration of SS; complex reaction; technology at an early stage, expensive technology with large capital [91-95].

\subsection{Gasification}

The gasification process involves partial oxidation with different gasifying agents (oxygen, air and steam) (Fig. 6) [96]. The gasification process of the sewage sludge is used to produce electricity, the energy conversion efficiency has a proportion of $14 \%-30 \%$, but it needs a series of steps to clean the gas of contaminants, which are: tars, heavy metals, dust, acid gases and sulfur. All these cause corrosion and harmful effect for human health and environment [97]. The gas resulting from the gasification process is rich in hydrogen $\mathrm{H}_{2}$, which means that it can be used as an alternative fuel [98].

The gasification process with the help of air results a mixture of $\mathrm{CO}, \mathrm{CO}_{2}, \mathrm{H}_{2}, \mathrm{CH}_{4}, \mathrm{~N}_{2}$ and tar. This mixture has combustion difficulties, especially in a turbine, because the calorific

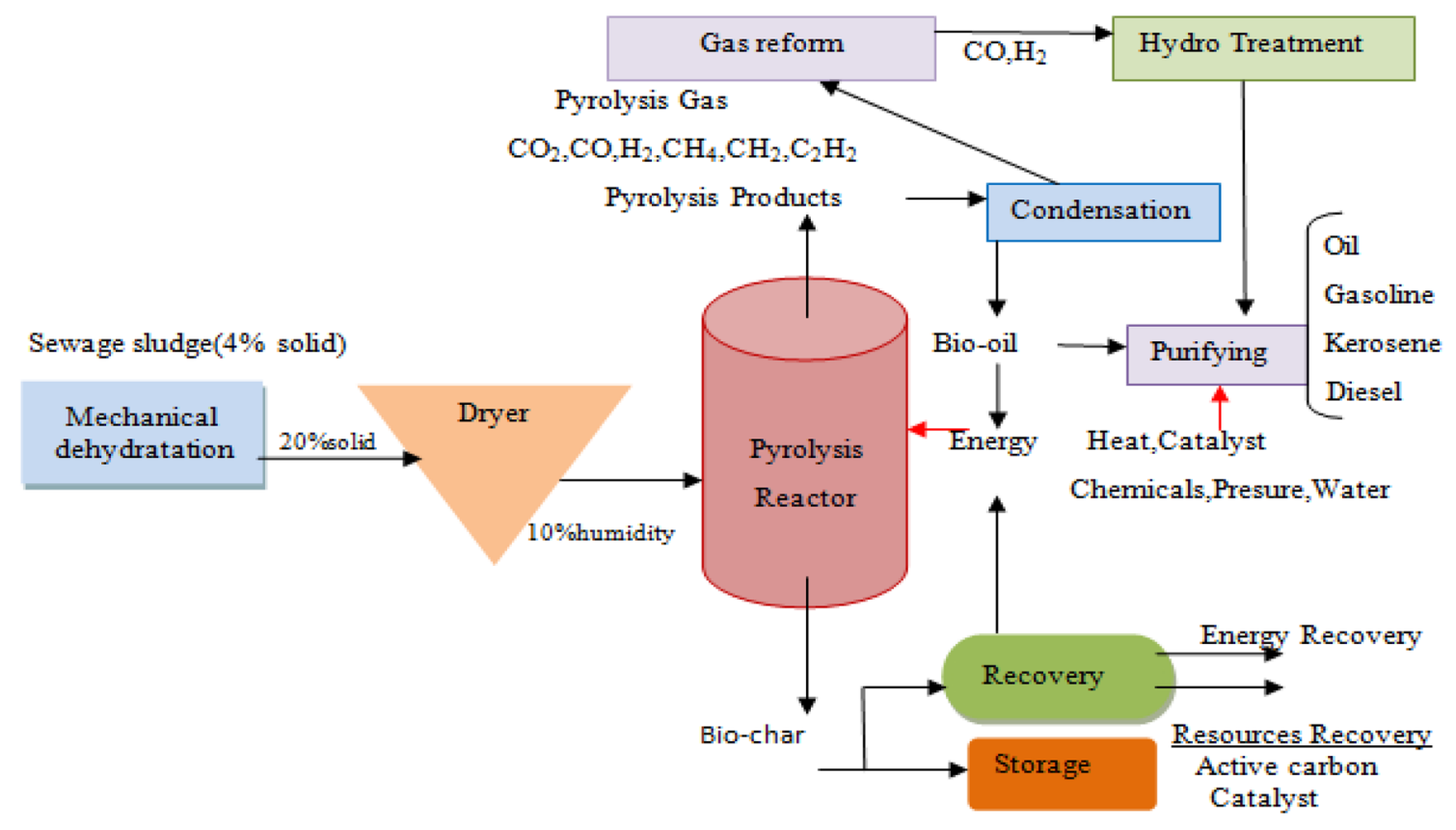

Fig. 5 Pyrolysis of sewage sludge according to [35] 


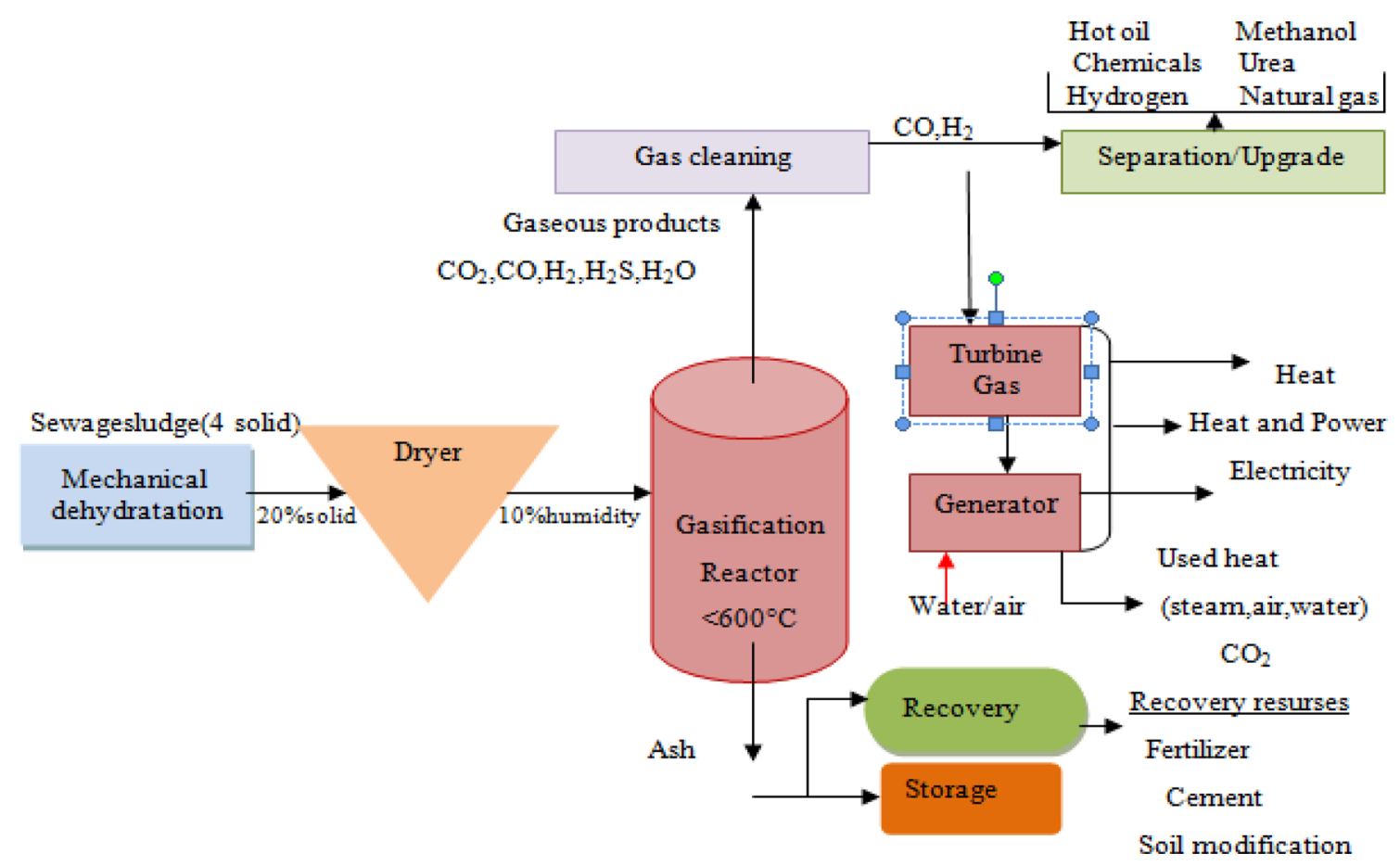

Fig. 6 Gasification processof sewage sludge [96]

value of the gas is $5 \mathrm{MJ} / \mathrm{m}^{3}[99,100]$. If oxygen is used in the gasification process, the calorific value of the resulting gas can reach a value of $10 \mathrm{MJ} / \mathrm{m}^{3}$ up to $12 \mathrm{MJ} / \mathrm{m}^{3}$, and nitrogen is missing from the gaseous product. The difference between using oxygen or air is both in quality and cost. Oxygen is more expensive, but the quality of the resulting gas is clearly superior. If steam is used, the concentration of methane and hydrocarbons increases, thus changing the proportions of the components. The gas obtained from the gasification process has a calorific value of $15 \mathrm{MJ} / \mathrm{m}^{3}$ up to $20 \mathrm{MJ} / \mathrm{m}^{3}$. The sequence of events during the gasification process is as follows: evaporation of moisture from the raw material, gas production, oil production and then the solid residue [101-103].

The advantages of the gasification process are: energy efficient technology; liquid fuel potential; stand-alone technology; waste in small quantities; low emissions; favoring the treatment plants from an economic point of view; low carbon potential for the energy industry. The disadvantages are the following: requirements for dehydration of SS; complex reaction; release of heavy metals and organic pollutants having toxic effects; expensive technology with high capital and operating costs [104].

\section{Conclusions and future remarks}

Sewage sludge is a complex matrix consisting of several residual products, such as biomass waste, paper and cardboard, microplastics, textiles, waste oils, traces of fossil fuels, human and animal feces, traces of drugs. This viscous matrix has an extremely high moisture content $>80 \%$. However, the organic composition makes it attractive for the energy sector.

From an environmental point of view, the pyrolysis process provides more advantages because it produces minimal amounts of waste, low emissions, low level of heavy metals than those resulted from the gasification and incineration processes. In terms of technology, the pyrolysis process is the most efficient due to its final products, oil, gas and solid residues that can be used as catalysts. Instead, the combustion process generates heat, the gasification process is energy efficient, but the reaction is complex and releases organic pollutants, heavy metals and other toxic pollutants. Considering incineration, the resulting ash requires its elimination. Also, during this process $\mathrm{CO}_{2}, \mathrm{NOx}$, and $\mathrm{SOx}$ are released. 
The economic advantages of low carbon potential for the energy industry advocates for the use of pyrolysis and gasification processes. An economic advantage for incineration is the existing infrastructure that can be used. But incineration may become expensive due to the requirement for the ash removal, pollutant control and technological cleaning. Gasification and pyrolysis processes also require a large investment capital.

Funding The authors did not receive support from any organization for the submitted work.

\section{Declarations}

Conflict of interest The authors have no relevant financial or nonfinancial interests to disclose.

Open Access This article is licensed under a Creative Commons Attribution 4.0 International License, which permits use, sharing, adaptation, distribution and reproduction in any medium or format, as long as you give appropriate credit to the original author(s) and the source, provide a link to the Creative Commons licence, and indicate if changes were made. The images or other third party material in this article are included in the article's Creative Commons licence, unless indicated otherwise in a credit line to the material. If material is not included in the article's Creative Commons licence and your intended use is not permitted by statutory regulation or exceeds the permitted use, you will need to obtain permission directly from the copyright holder. To view a copy of this licence, visit http://creativecommons. org/licenses/by/4.0/.

\section{References}

1. Collivignarelli MC, Abba A, Miino MC, Torretta V (2019) What advanced treatments can be used to minimize the Production of sewage sludge in WWTPs? Appl Sci 9(13):2650. https://doi. org/10.3390/app9132650

2. Djandja OS, Yin L-X, Wang Z-C, Duan P-G (2021) From wastewater treatment to resources recovery through hydrothermal treatments of municipal sewage sludge: A critical review. Process afety and environmental protection 151:101-127. https:// doi.org/10.1016/j.psep.2021.05.0060

3. Eurostat (2018) Total sewage sludge production from urban wastewater. https://ec.europa.eu/eurostat/databrowser/view/ ten00030/default/table?lang=en.

4. Wang Z, Xie L, Liu K, Wang J, Zhu H, Song Q, Shu X (2019) Copyrolysis ofsewage sludge and cotton stalks. Waste Manag 89:430-438. https://doi.org/10.1016/j.wasman.2019.04.033

5. Cieslik BM, Namieśnik J, Konieczka P (2015) Review of sewage sludge management:standards, regulations and analytical methods. J Clean Prod 90:1-15. https://doi.org/10.1016/j.jclep ro.2014.11.031

6. Kelessidis A, Stasinakis AS (2012) Comparative study of the methods used fortreatment and final disposal of sewage sludge in European countries. Waste Manage 32(6):1186-1195. https://doi.org/10.1016/j.wasman.2012.01.012

7. Zhen G, Lu X, Kato H, Zhao Y, Li YY (2017) Overview of pretreatment strategies for enhancing sewage sludge disintegration and subsequent anaerobic digestion: Current advances, full-scale application and future perspectives. Renew Sustain Energy Rev 69:559-577. https://doi.org/10.1016/j.rser.2016.11. 187

8. Rusu T, Rusu TA (2014) Tehnologii și echipamente pentru tratarea și epurarea apelor. Cluj-Napoca, Romania

9. Eurostat. Total sewage sludge usage from urban wastewater. http://epp.eurostat.ec.europa.eu

10. Paz-Ferreiro J, Nieto A, Méndez A, James Askeland MP, Gascó G (2018) Biochar from biosolids pyrolysis: a review. Int J Environ Res Public Health 15(5):956. https://doi.org/10.3390/ijerph1505 0956

11. Racek J, Sevcik J, Chorazy T, Kucerik J, Hlavinek P (2019) Biochar-recovery material from pyrolysis of sewage sludge: a review. Waste Biomass Valorizat 11:3677-3709. https://doi.org/ 10.1007/s12649-019-00679-w

12. Leng L-J, Yuan $X-Z$, Huang $H$, Wang $H$, Wu Z, Fu L-H, Peng $X$, Chen $X-H$, Leng $L$ (2015) Characterization and application of biochars from liquefaction of microalgae, lignocellulosic biomass and sewage sludge. Fuel Process Technol 129:8-14. https://doi.org/10.1016/j.fuproc.2014.08.016

13. Mendez A, Cárdenas-Aguiar E, Paz-Ferreiro J, Plaza C, Gascó $G$ (2017) The effect of sewage sludge biochar on peat-based growing media. Biol Agric Hortic 33:40-51. https://doi.org/10. 1080/01448765.2016.1185645

14. Vardon DR, Sharma BK, Blazina GV, Rajagopalan K, Strathmann TJ (2012) Thermochemical conversion of raw and defatted algal biomass via hydrothermal liquefaction and slow pyrolysis. Bioresour Technol 109:178-187. https://doi.org/10.1016/j. biortech.2012.01.008

15. Ronda A, Della Zassa M, Gianfelice G, láñez-Rodríguez I, Canuet $P$ (2019) Smouldering of different dry sewage sludges and residual reactivity of their intermediates. Fuel 247:148-159. https://doi.org/10.1016/j.fuel.2019.03.026

16. Yesil $H$, Rugtas A (2019) Removal of heavy metals from leaching effluents of sewagesludge via supported liquid membranes. Sci Tot Environ 693:133608. https://doi.org/10.1016/j.scitotenv. 2019.133608

17. Tian K, Liu WJ, Qian TT, Jiang H, Yuet HQ (2014) Investigation on the evolution of $\mathrm{N}$-containing organic compounds during pyrolysis of sewage sludge. Environ Sci Technol 48(18):1088810896. https://doi.org/10.1021/es5022137

18. Duan XY, Cao Y, Liu TZ, Li L, Wang B, Wang XD (2020) Nutrient stabilityand sorption of sewage sludge biochar prepared from co-pyrolysis of sewage sludge and stalks/mineral materials. Environ Pollut Bioavail 32(1):12-18. https://doi.org/10.1080/ 26395940.2019.1710259

19. Liu T, Guoc Y, Penga N, Langa Q, Xia Y, Gai C, Liu Z (2017) Nitrogen transformation among char, tar and gas during pyrolysis of sewage sludge and corresponding hydrochar. J Anal Appl Pyrol 126:298-306. https://doi.org/10.1016/j.jaap.2017.05.017

20. Qi G, Xiong L, Luo M, Huang Q, Huang C, Li H, Chen X (2018) Solvents production from cassava by co-culture of Clostridium acetobutylicum and Saccharomyces cerevisiae. J Environ Chem Eng 6(1):128-133. https://doi.org/10.1016/j.jece.2017.11.067

21. Zhang J, Tian Y, Cui Y, Zuo W, Tan T (2013) Key intermediates in nitrogen transformation during microwave pyrolysis of sewage sludge: a protein model compound study. Bioresour Technol 132:57-63. https://doi.org/10.1016/j.biortech.2013.01.008

22. Zheng A, Anqing Z, Luwei L, Nakorn T, Zhen H, Kun Z, Guoqiang W, Zengli Z, Haibin L (2020) Reducing emission of NOx and SOx precursors while enhancing char production from pyrolysis of sewage sludge by torrefaction pretreatment. Energy 192:116620. https://doi.org/10.1016/j.energy.2019.116620

23. Shen $Y, H e C$, Chen X, Lapkin AA, Xiao W, Wang CH (2018) Nitrogenremoval and energy recovery from sewage sludge by combined hydrothermal pretreatment and $\mathrm{CO}_{2}$ gasification. ACS 
Sustain Chem Eng 6(12):16629-16636. https://doi.org/10.1021/ acssuschemeng.8b03857

24. Liu H (2014) Catalytic role of conditioner $\mathrm{CaO}$ in nitrogen transformation duringsewage sludge pyrolysis. Fuel 134(9):514-520

25. Wang W, Zheng Y, Zhu X, Brewer CE, Brown RC (2017) Ex-situ catalytic pyrolysis of wastewater sewage sludge-a micropyrolysis study. Bioresour Technol 232:229-234. https://doi. org/10.1016/j.biortech.2017.02.015

26. Wei F, Cao JP, Zhao XY, Ren J, Wang JX, Fan X, Wei XY (2017) Nitrogen evolution during fast pyrolysis of sewage sludge under inert and reductive atmospheres. Energy Fuels 31(7):7191-7719. https://doi.org/10.1021/acs.energyfuels. $7 \mathrm{~b} 00920$

27. Gu B, Cao JP, Shan YF, Wei F, Zhao M, Zhao YP, Zhao YX, Wei XY (2020) Catalytic fast pyrolysis of sewage sludge over HZSM-5: a study of light aromatics, coke and nitrogen migration under different atmospheres. Ind Eng Chem Res 59:17537-17545. https://doi.org/10.1021/acs.iecr.0c01170

28. Cao JP, Shi P, Zhao XY, Wei XY, Takarada T (2014) Catalytic reforming ofvolatiles and nitrogen compounds from sewage sludge pyrolysis to clean hydrogen and synthetic gas over a nickel catalyst. Fuel Process Technol 123:34-40. https://doi.org/ 10.1016/j.fuproc.2014.01.042

29. Gu B, Cao JP, Wei F, Zhao XY, Ren XY, Zhu C, Guo ZX, Bai J, Shen WZ, Wei XY (2019) Nitrogen migration mechanism and formation of aromatics during catalytic fast pyrolysis of sewage sludge over metal-loaded HZSM-5. Fuel 244:151-158. https:// doi.org/10.1016/j.fuel.2019.02.005

30. Liu H, Yi L, Hu H, Xu K, Zhang Q, Lu G, Yao H (2017) Emission control ofNOx precursors during sewage sludge pyrolysis using an integrated pretreatment of Fenton peroxidation and $\mathrm{CaO}$ conditioning. Fuel 195:208-216. https://doi.org/10.1016/j.fuel. 2017.01.067

31. Gogola K, Rogala T, Magdziarczyk M, Smolinski A (2020) The mechanisms of endogenous fires occurring in extractive waste dumping facilities. Sustainability 12:2856. https://doi.org/10. 3390/su12072856

32. Werle S, Wilk RK (2010) A review of methods for the thermal utilization of sewagesludge: the Polish perspective. Renew Energy 35:1914-1919. https://doi.org/10.1016/j.renene.2010.01.019

33. Urych B, Smolinski A (2016) Kinetics of sewage sludge pyrolysis and air gasification of its chars. Energy Fuels 30(6):4869-4878. https://doi.org/10.1021/acs.energyfuels.6b00332

34. Ledakowicz S, Stolarek P, Malinowski A, Lepez O (2019) Thermochemical treatment of sewage sludge by integration of drying and pyrolysis/autogasification. Renew Sustain Energy Rev 104:319-327. https://doi.org/10.1016/j.rser.2019.01.018

35. Xie Q, Peng P, Liu S, Min M, Cheng Y, Wan Y, Li Y, Lin X, Liu Y, Chen $P(2014)$ Fast microwave-assisted catalytic pyrolysis of sewage sludge for bio-oil production. Bioresour Technol 172:162-168. https://doi.org/10.1016/j.biortech.2014.09.006

36. Collard M, Benoit T, Lemee L (2017) Comparison of three different wastewatersludge and their respective drying processes: solar, thermal and reed beds-Impact on organic matter characteristics. J Environ Manag 203:760-767. https://doi.org/10. 1016/j.jenvman.2016.05.070

37. Cao Y, Pawłowski A (2012) Sewage sludge-to-energy approaches based on anaerobicdigestion and pyrolysis: brief overview and energy efficiency assessment. Renew Sustain Energy Rev 16(3):1657-1665. https://doi.org/10.1016/j.rser. 2011.12.014

38. Tytła M, Widziewicz K, Zielewicz E (2016) Heavy metals and its chemicalspeciation in sewage sludge at different stages of processing. Environ Technol 37(7):899-908. https://doi.org/10. 1080/09593330.2015.1090482
39. Spanos T, Ene A, Styliani Patronidou C, Xatzixristos C (2016) Temporal variabilityof sewage sludge heavy metal content from Greek wastewater treatment plants. Ecol Chem Eng 23:271-283. https://doi.org/10.1515/eces-2016-0019

40. Kan T, Strezov V, Evans T (2012) Effect of the heating rate on the thermochemical behavior and biofuel properties of sewage sludge pyrolysis. Energy Fuels 30:1564-1570. https://doi.org/ 10.1021 /acs.energyfuels.5b02232

41. Buta M, Hubeny J, Zielinski W, Harnisz M, Korzeniewska E (2021) Sewage sludge in agriculture-the effects of selected chemical pollutants and emerging genetic resistance determinants on the quality of soil and crops-a review. Ecotoxicol Environ Saf 214:112070. https://doi.org/10.1016/j.ecoenv.2021.112070

42. Siebielec G, Siebielec S, Lipski D (2018) Long-term impact of sewage sludge, digestateand mineral fertilizers on plant yield and soil biological activity. J Clean Prod 187:372-379

43. Bai Y, Zang C, Gu M, Gu C, Shao H, Guan Y, Wang X, Zhou X, Shan Y, Feng K (2017) Sewage sludge as an initial fertility driver for rapid improvement of mudflatsalt-soils. Sci Total Environ 578:47-55

44. Gonzaga MIS, Mackowiak CL, Comerford NB, Moline EFV, Shirley JP (2017) Pyrolysis methods impact biosolids-derived biocharcomposition, maize growth and nutrition. Soil Tillage Res 165:59-65

45. Fang W, Delapp RC, Kosson DS, Van Der Sloot HA, Liu J (2017) Release of heavymetals during long-term land application of sewage sludge compost: percolationleaching tests with repeated additions of compost. Chemosphere 169:271-280

46. Hei L, Jin P, Zhu X, Ye W, Yang Y (2016) Characteristics of speciation of heavymetals in municipal sewage sludge of guangzhou as fertilizer. Proc Environ Sci 31:232-240

47. Hernandez T, Chocano C, Moreno JL, García C (2016) Use of compost as analternative to conventional inorganic fertilizers in intensive lettuce (Lactuca sativa L.) crops-effects on soil and plant. Soil Tillage Res 160:14-22

48. Martins MN, Souza VV, Souza TS (2016) Genotoxic and mutagenic effects of sewagesludge on higher plants. Ecotoxicol Environ Saf 124:489-496

49. Annabi $M$, Le Bissonnais $Y$, Le Villio-Poitrenaud $M$, Houot $S$ (2011) Improvementof soil aggregate stability by repeated applications of organic amendments to a cultivated silty loam soil. Agric Ecosyst Environ 144:382-389. https://doi.org/10. 1016/j.agee.2011.07.005

50. Singh RP, Agrawal M (2008) Potential benefits and risks of land application of sewage sludge. Waste Manag 28:347-358. https://doi.org/10.1016/j.wasman.2006.12.010

51. Latare AM, Kumar O, Singh SK, Gupta A (2014) Direct and residual effect ofsewage sludge on yield, heavy metals content and soil fertility under rice-wheat system. Ecol Eng 69:17-24. https://doi.org/10.1016/j.ecoleng.2014.03.066

52. Hamdi H, Benzarti S, Manusadžianas L, Aoyama I, Jedidi N (2007) Solid-phase bioassays and soil microbial activities to evaluate PAH-spiked soil ecotoxicity after a long-term bioremediation process simulating landfarming. Chemosphere 70(1):135-143. https://doi.org/10.1016/j.chemosphere.2007. 06.043

53. Galafassi S, Nizzetto L, Volta P (2019) Plastic sources: A survey across scientific andgrey literature for their inventory and relative contribution to microplastics pollution in natural environments, with an emphasis on surface water. Sci Total Environ 693:133499. https://doi.org/10.1016/j.scitotenv.2019.07.305

54. Ben Achiba W, Lakhdar A, Gabteni N, Du Laing G, Verloo M, Boeckx P, Van Cleemput O, Jedidi N, Gallali T (2010) Accumulation and fractionation of trace metals in a Tunisian calcareous soil amended with farmyard manure and municipal solid waste 
compost. J Hazard Mater 176:99-108. https://doi.org/10.1016/j. jhazmat.2009.11.004

55. Roig N, Sierra J, Martí E, Nadal M, Schuhmacher M, Domingo JL (2012) Longterm amendment of Spanish soils with sewage sludge: effects on soil functioning. Agric Ecosyst Environ 158:41-48. https://doi.org/10.1016/j.agee.2012.05.016

56. Van Cauwenberghe L, Devriese L, Galgani F, Robbens J, Janssen CR (2015) Microplastics in sediments: a review of techniques, occurrence and effects. Mar Environ Res 111:5-17. https://doi. org/10.1016/j.marenvres.2015.06.007

57. Petrie B, Barden R, Kasprzyk-Hordern B (2014) A review on emerging contaminantsin wastewaters and the environment: current knowledge, understudied areas and recommendations for future monitoring. Water Res 72:3-27. https://doi.org/10. 1016/j.watres.2014.08.053

58. Ivanova L, Mackulak T, Grabic R, Golovko O, Koba O, Stanova AV, Szabova P, Grencíkova A, Bodík I (2018) Pharmaceuticals and illicit drugs - a new threat to theapplication of sewage sludge in agriculture. Sci Total Environ 634:606-615

59. Konczak M, Oleszczuk P (2018) Application of biochar to sewage sludge reducestoxicity and improve organisms growth in sewage sludge-amended soil in long termfield experiment. Sci Total Environ 625:8-15

60. Melo W, Delarica D, Guedes A, Lavezzo L, Donha R, Araújo A, Melo G, Macedo F (2018) Ten years of application of sewage sludge on tropical soil. Abalance sheet on agricultural crops and environmental quality. Sci Total Environ 643:1493-1501

61. Ivarenga $P$, Mourinha $C$, Farto $M$, Santos $T$, Palma P, Sengo J, Morais MC, Cunha-Queda C, (2015) Sewage sludge, compost and other representative organicwastes as agricultural soil amendments: benefits versus limiting factors. Waste Manag 40:44-52

62. Iranzo M, Gamon M, Boluda R, Mormeneo S (2018) Analysis of pharmaceuticalbiodegradation of WWTP sludge using composting and identification of certain microorganisms involved in the process. Sci Total Environ 640-641:840-848

63. Flie Bbach A, Martens R, Reber HH (1994) Soil microbial biomass and microbial activity in soils treated with heavy metal contaminated Sewage Sludge. Soil Biol Biochem 26(9):12011205. https://doi.org/10.1016/0038-0717(94)90144-9

64. Knight BP, Mc Grath SP, Chadri AM (1997) Biomass carbon measurements substrate utilization patterns of microbial populations from soils amended with cadmium, copper or zinc. Appl Environ Microbiol 663:39-43

65. Baath E (1989) Effects of heavy metals in soil on microbial process and populations-a review. Water Air Soil Pollut 4:335-379

66. McGrath SP, Brookes PC, Giller KE (1988) Effects of potentially toxic metals in soil derived from past applications of sewage sludge on nitrogen fixation by Trifolium repens L. Soil Biol Biochem 20:415-424. https://doi.org/10.1016/0038-0717(88) 90052-1

67. Martín J, Santos JL, Aparicio I, Alonso E (2015) Pharmaceutically activecompoundsinsludge stabilization treatments: anaerobic and aerobic digestion, wastewater stabilization pondsandcomposting. Sci Tot Environ 503-504:97-104. https://doi.org/10. 1016/j.scitotenv.2014.05.089

68. Zhou C, Li Y, Peng Y, Ye C, Zhang S (2021) Effects of antibiotics on hydrolase activity and structure of microbial community during co-composting of food with sewage sludge. Bioresour Technol 321:124506. https://doi.org/10.1016/j.biortech.2020. 124506

69. Michaela I, Rizzob L, McArdellc CS, Manaiad CM, Merline C, Schwartzf T, Dagotg C, Fatta-Kassinosa D (2013) Urban wastewater treatment plants as hotspots for therelease of antibiotics in the environment: a review. Water Res 47:957-995. https:// doi.org/10.1016/j.watres.2012.11.027

70. McGrath JW, Hammerschmidt F, Quinn JP (1998) Biodegradation ofphosphonomycin by Rhizobium huakuii PMY1. Appl Environ Microbiol 64:356-358. https://doi.org/10.1128/AEM. 64.1.356-358.1998

71. Syed-Hassan SSA, Wang Y, Hu S, Su S, Xiang J (2017) Thermochemicalprocessing of sewage sludge to energy and fuel: fundamentals, challenges and considerations. Renew Sustain Energy Rev 80:888-913. https://doi.org/10.1016/j.rser.2017.05. 262

72. Magdziarz A, Wilk M (2013) Thermogravimetric study of biomass, sewage sludge and coal combustion. Energy Convers Manag 75:425-430. https://doi.org/10.1016/j.enconman.2013. 06.016

73. Mulchandani A, Westerhoff P (2016) Recovery opportunities for metals and energyfrom sewage sludges. Bioresour Technol 215:215-226. https://doi.org/10.1016/j.biortech.2016.03.075

74. Seiple TE, Coleman AM, Skaggs RL (2017) Municipal wastewater sludge as a sustainable bioresource in the United States. J Environ Manag 197:673-680. https://doi.org/10.1016/j.jenvm an.2017.04.032

75. Murakami T, Suzuki Y, Nagasawa H, Yamamoto T, Koseki T, Hirose H, Okamoto S (2009) Combustion characteristics of sewage sludge in an incineration plant for energyrecovery. Fuel Process Technol 90:778-783. https://doi.org/10.1016/j.fuproc. 2009.03.003

76. Chimenos JM, Segarra M, Fernández MA, Espiell F (1999) Characterization of the bottom ash in municipal solid waste incinerator. J Hazard Mater 64(3):211-222. https://doi.org/10.1016/ S0304-3894(98)00246-5

77. Keulen A, van Zomeren A, Harpe P, Aarnink W, Simons HAE, Brouwers HJH (2016) High performance of treated and washed MSWI bottom ash granulates as natural aggregate replacement within earth-moist concrete. Waste Manag 49:83-95. https:// doi.org/10.1016/j.wasman.2016.01.010

78. Silva RV, de Brito J, Lynn CJ, Dhir RK (2017) Use of municipal solid waste incineration bottom ashes in alkali-activated materials, ceramics and granular applications: a review. Waste Manage 68:207-220. https://doi.org/10.1016/j.wasman.2017.06.043

79. Werther J, Ogada T (1999) Sewage sludge combustion. Progress Energy Combust Sci 25(1):55-116. https://doi.org/10.1016/ S0360-1285(98)00020-3

80. Raheem A, Sikarwar VS, He J, Dastyar W, Dionysiou DD, Wang W, Zhao M (2018) Opportunities and challenges in sustainabletreatment and resource reuse of sewage sludge: a review. Chem Eng J 337:616-641. https://doi.org/10.1016/j.cej.2017. 12.149

81. Donatello S, Cheeseman CR (2013) Recycling and recovery routes for incineratedsewage sludge ash (ISSA): a review. Waste Manag 33:2328-2340. https://doi.org/10.1016/j.wasman.2013. 05.024

82. Zaharioiu A, Bucura F, lonete El, lonete RE, Ebrasu D, Sandru C, Marin F, Oancea S, Niculescu V, Miricioiu MG, Constantinescu M (2020) Thermochemical descomposition of sewage sludge-an eco-friendly solution for a sustainable energy future by using wastes. Revista de Chimie 71(10):171-181. https://doi.org/10. 37358/Rev.Chim.1949

83. Aysu T, Durak H, Guner S, Bengu AS, Esim N (2016) Bio-oil production via catalytic pyrolysis of Anchusa azurea: effects of operating conditions on products yelds and chromatographic characterisation. Bioresour Technol 205:7-14. https://doi.org/ 10.1016/j.biortech.2016.01.015

84. Stolarek P, Ledakowicz S, Ślęzak R (2019) Influence of liming on kinetics of sewage sludge pyrolysis. Ecol Chem Eng S 20:175188. https://doi.org/10.1515/eces-2019-0013 
85. Anca-Couce A (2016) Reaction mechanisms and multi-scale modelling of lignocellulosic biomass pyrolysis. Progress Energy Combust Sci 53:41-79. https://doi.org/10.1016/j.pecs.2015.10. 002

86. Khalid A, Aslam M, Qyyum MA, Faisal A, Khan AL, Ahmed F, Lee M, Kim J, Jang N, In Chang S, Bazmi AA, Yasin M (2019) Membrane separation processes for dehydration of bioethanol from fermentation broths: recent developments, challenges, and prospects. Renew Sustain Energy Rev 105:427-443. https:// doi.org/10.1016/j.rser.2019.02.002

87. Maaz M, Yasin M, Aslam M, Kumar G, Atabani AE, Idrees M, Anjum F, Jamil F, Ahmad R, Khan AL (2019) Anaerobic membrane bioreactors for wastewater treatment: Novel configurations, fouling control and energy considerations. Bioresour Technol 283:358-372. https://doi.org/10.1016/j.biortech.2019. 03.061

88. Saqib S, Rafiq S, Chawla M, Saeed M, Muhammad N, Khurram S, Majeed K, Khan AL, Ghauri M, Jamil F (2019) Facile $\mathrm{CO}_{2}$ separation in composite membranes. Chem Eng Technol 42:30-44. https://doi.org/10.1002/ceat.201700653

89. Tahir Z, Aslam M, Gilani MA, Bilad MR, Anjum MW, Zhu L-P, Khan A-L (2019) $\mathrm{SO}_{3} \mathrm{H}$ functionalized UiO-66 nanocrystals in Polysulfone based mixed matrix membranes: synthesis and application for efficient $\mathrm{CO}_{2}$ capture. Sep Purif Technol 224:524-533. https://doi.org/10.1016/j.seppur.2019.05.060

90. Zaker A, Chen Z, Wang X, Zhang Q (2019) Microwave-assisted pyrolysis of ewagesludge: a review. Fuel Process Technol 187:84-104. https://doi.org/10.1016/j.fuproc.2018.12.011

91. Jin J, Li Y, Zhang J, Wu S, Cao Y, Liang P, Zhang J, Wong MH, Wang M, Shan S (2016) Influence of pyrolysis temperature on properties and environmental safety of heavy metals in biochars derived from municipal sewage sludge. J Hazard Mater 320:417-426. https://doi.org/10.1016/j.jhazmat.2016.08.050

92. Gao N, Quan C, Liu B, Li Z, Wu C, Li A (2017) Continuous pyrolysis of sewagesludge in a screw-feeding reactor: products characterization and ecological risk assessment of heavy metals. Energy Fuels 31:5063-5072. https://doi.org/10.1021/acs.energ yfuels.6b03112

93. Chen T, Zhang Y, Wang H, Lu W, Zhou Z, Zhang Y, Ren L (2014) Influence of pyrolysis temperature oncharacteristics and heavy metal adsorptive performance of biochar derived from municipal sewage sludge. Bioresour Technol 164:47-54. https://doi. org/10.1016/j.biortech.2014.04.048

94. Longo S, Katsou E, Malamis S, Frison N, Renzi D, Fatone F (2015) Recovery of volatile fatty acids from fermentation of sewage sludge in municipal wastewater treatment plants. Bioresour Technol 175:436-444. https://doi.org/10.1016/j.biortech.2014. 09.107
95. Zhuang L, Zhou S, Wang Y, Liu Z, Xu R (2011) Cost-effective production of Bacillus thuringiensis biopesticides by solid-state fermentation using wastewater sludge: effects of heavy metals. Bioresour Technol 102:4820-4826. https://doi.org/10.1016/j. biortech.2010.12.098

96. Roche E, de Andrés JM, Narros A, Rodríguez ME (2014) Air and air-steamgasification of sewage sludge. The influence of dolomite and throughput in tar production and composition. Fuel 115:54-61. https://doi.org/10.1016/j.fuel.2013.07.003

97. Woolcock PJ, Brown RC (2013) A review of cleaning technologies for biomass-derived syngas. Biomass Bioenergy 52:54-84. https://doi.org/10.1016/j.biombioe.2013.02.036

98. Zheng X, Ying Z, Wang B, Chen C (2018) Hydrogen and syngas production from municipal solid waste (MSW) gasification via reusing $\mathrm{CO}_{2}$. Appl Therm Eng 144:242-247. https://doi.org/10. 1016/j.applthermaleng.2018.08.058

99. Bridgwater AV (1990) A survey of thermochemical biomass processing activities. Biomass 22(1-4):279-290

100. Yang L, Ran C, Siddiqui AR, Chudaeva P, Sial AA, Song Y, Dai J, Deng Z, Fu J, Ao W, Jiang Z, Zhang T (2020) Pyrolysis of sewage sludge in a benchtop fluidized bed reactor: characteristics of condensates and non-condensable gases. Renew Energy 160:707-720. https://doi.org/10.1016/j.renene.2020.06.137

101. Bridgwater AV (1994) Catalysis in thermal biomass conversion. Appl Catal 116(1-2):5-47. https://doi.org/10.1016/0926860X(94)80278-5

102. Mohr K, Nonn C, Kolenda J, Gass H, Menke D, Jager J (1998) Innovations in continuous measuring methods for the determination of PCDD/PCDF in stack gas of incinerators and thermal processes. Chemosphere 37:2409-2424. https://doi.org/10. 1016/S0045-6535(98)00298-7

103. Chanaka Udayanga WD, Veksha A, Giannis A, Lisak G, Lim TT (2019) Effects of sewage sludge organic and inorganic constituents on the properties of pyrolysis products. Energy Convers Manag 196:1410-1419. https://doi.org/10.1016/j.enconman. 2019.06.025

104. Smolinski A, Howaniec N, Ba KA (2018) Utilization of energy crops and sewagesludge in the process of co-gasification for sustainable hydrogen production. Energies 11:809. https://doi. org/10.3390/en11040809

Publisher's Note Springer Nature remains neutral with regard to jurisdictional claims in published maps and institutional affiliations. 